\title{
Four Tier-Magnetic Diagnostic Test (4T-MDT): Instrumen Evaluasi Medan Magnet Untuk Mengidentifikasi Miskonsepsi Siswa
}

\author{
Irnin Agustina Dwi Astuti ${ }^{\star}$, Yoga Budi Bhakti, dan Rendi Prasetya \\ Universitas Indraprasta PGRI \\ Jl. Raya Tengah, Kp. Gedong, Kec. Pasar Rebo, Jakarta Timur \\ *E-mail: irnin.agustina@gmail.com
}

\begin{abstract}
Abstrak
Miskonsepsi fisika merupakan perbedaan pemahaman konsep yang diketahui oleh siswa dengan konsep sebenarnya. Profil miskonsepsi fisika siswa harus diidentifikasi agar siswa memiliki pemahaman konsep yang benar. Tes diagnostik sebagai solusi untuk mengungkap penyebab atau faktor kesalahpahaman konsep fisika pada siswa. Salah satu jenis tes diagnostic adalah 4 tier test. Tujuan penelitian ini untuk mengetahui kelayakan instrumen 4 Tier-Magnetic Diagnostic Test (4T-MDT) dalam mengidentifikasi miskonsepsi pada siswa. Penelitian ini $R$ \& D dengan 4D model. Instrumen 4T-MDT yang dibuat terdiri dari 20 pertanyaan pilihan ganda. Setelah instrument 4T-MDT divalidasi, maka diperoleh rata-rata penilaian sebesar $84 \%$ yang berarti layak digunakan dan diimplementasikan ke siswa. Hasil uji coba menunjukkan sebanyak 15 item pada instrumen 4T-MDT sudah valid, memiliki reliabilitas yang tinggi, daya beda yang baik, serta tingkat kesukaran yang baik. Sehingga instrumen 4T-MDT berfungsi untuk mengidentifikasi profil miskonsepsi fisika siswa pada konsep medan magnetik.
\end{abstract}

Kata kunci: medan magnet, tes diagnostik, four tier test, miskonsepsi fisika.

\begin{abstract}
The misconception of physics is a difference in understanding concepts known to students with actual concepts. The student's physics misconception profile must be identified for the student to have a correct understanding of the concept-diagnostic tests as a solution to uncover the causes or factors of misunderstanding the physics concept in students. One type of diagnostic test is 4 tier tests. The purpose of this study was to see if the 4th Tier-Magnetic Diagnostic Test (4T-MDT) can help students identify misconceptions. The study was R\&D with a 4D model. The 4T-MDT instrument consists of 20 multiple choice questions. Once the 4T-MDT instrument is validated, an average assessment of $84 \%$ is obtained, which means it is worth using and implemented to students. The test results showed that as many as 15 items on the 4T-MDT instrument were valid, had high reliability, different good power, and a good difficulty level. As a result, the 4T-MDT instrument may be used to identify the profile of student physics mistakes about magnetic fields.
\end{abstract}

Keywords: magnetic field, diagnostic test, four tier test, physics misconceptions.

\section{PENDAHULUAN}

Penguasaan konsep dan pengembangan keterampilan proses sains siswa merupakan salah satu tujuan dari pembelajaran fisika di sekolah. Dengan belajar fisika, diharapkan siswa memiliki penguasaan konsep dan keterampilan proses sains yang baik. Pemahaman konsep merupakan salah satu faktor penting dalam pembelajaran fisika. Salah satu materi fisika yang dipelajari di SMA
Kelas XII adalah materi medan magnet. Materi medan magnetik terdiri dari medan magnet, gaya magnet dan aplikasi medan magnet (Setyaningsih et al., 2018). Konsep materi medan magnetik tersebut harus bisa dipahami dengan baik oleh siswa baik dari segi teori, implementasi teori maupun persamaan fisikanya.

Hasil observasi yang dilakukan di SMA Negeri 4 Semarang menyatakan bahwa 74\% siswa kelas XII menjawab medan magnet merupakan materi yang paling susah 
dimengerti. Sulitnya memahami konsep medan magnet dikarenakan terdapat banyak rumus dan kesalahan konsep dalam memahami materi. Strategi pembelajaran yang digunakan oleh guru menjadi faktor utama yang menyebabkan tingginya siswa mengalami kesalahpahaman dalam materi siswa. Sekitar $68 \%$ siswa SMA Negeri 4 Semarang tidak tertarik pada fisika. Ketidaktertarikan siswa pada materi fisika ditandai dengan sikap siswa dalam belajar fisika, diantaranya siswa tidak memperhatikan penjelasan materi oleh guru, tidak mendengar materi yang disampaikan guru. Selain itu, siswa tidak mempelajari materi terlebih dahulu sebelum materi tersebut dipelajari di sekolah, hal ini menyebabkan siswa tidak memiliki pengetahuan awal sehingga berdampak kepada tingginya kesalahpahaman siswa pada materi fisika. Berdasarkan hasil observasi, diketahui bahwa siswa lebih sering mengalami salah konsep, terutama pada materi medan magnet.

Kesalahan konsep atau yang sering disebut dengan miskonsepsi merupakan suatu kesalahan yang disebabkan dalam mengartikan konsep yang belum sesuai dengan teori (Zulvita \& Halim, 2017). Menurut Treagust, kesalahan siswa dalam memahami konsep akan menimbulkan penafsiran yang berbeda dan menyebabkan salah konsep (Treagust, 2012). Miskonsepsi sering terjadi apabila siswa tidak bisa menghubungkan dan memahami teori yang dipelajari di sekolah dengan fenomena ilmiahnya. Miskonsepsi adalah pola berpikir siswa yang menimbulkan kesalahpahaman antara teori dan yang dipahami oleh siswa (Astuti et al., 2018; Fakhrudin et al., 2012).

Kesalahpahaman dapat diminimalkan dengan cara identifikasi sedini mungkin. Salah satu bentuk identifikasi kesalahpahaman adalah memberikan diagnostic test kepada siswa. Tes diagnostik ini menjadi solusi dalam menemukan kesalahpahaman siswa. Tes diagnosis memiliki tiga jenis tingkatan. Pada penelitian ini mengembangkan instrument $4 \mathrm{~T}$ MDT.

Four-tier diagnostic test biasanya digunakan untuk mengetahui dan mengidentifikasi level tentang memahami konsep pada siswa pada tes 4 tingkat. Yang membedakan antara tes pilihan 3 tingkat dengan 4 tingkat adalah adanya penambahan tigkat keyakinan terhadap alasan terhadap jawaban soal tersebut. Pada instrumen tes 3 tingkat, keyakinan terhadap alasan dan jawaban tidak dipisah. Tetapi pada instrumen tes 4 tingkat, tingkat keyakinan terhadap jawaban dan alasan di pisah, sehingga dengan instrumen tes 4 tingkat, siswa dapat dikelompokkan yang memahami konsep, memahami konsep sebagian, tidak memahami konsep dan miskonsepsi (Caleon \& Subramaniam, 2010).

Kelebihan dari tes diagnostik 4 tingkat adalah perbedaan keyakinan siswa terhadap konsep antara siswa yang satu dan yang lainnya akan memudahkan guru untuk dapat ditelaah (Fariyani \& Rusilowati, 2015). Miskonsepsi pada siswa dapat menghambat siswa dalam menguasai konsep fisika dengan benar. Tujuan penelitian ini untuk mengetahui kelayakan instrumen 4T-MDT dalam mengidentifikasikan profil dan kesalahpahaman konsep siswa pada materi medan magnet.

\section{METODE}

Jenis penelitian ini yaitu Research \& Development (R\&D) untuk mengembangkan dan mengetahui kelayakan instrumen 4T-MDT untuk mengetahui miskonsepsi siswa pada materi medan magnet, dengan model pengembangan 4D yang meliputi tahap define, tahap design, tahap development, dan dissemination. Instrumen penelitian ini adalah lembar instrumen 4T-MDT dan lembar kelayakan instrumen 4T-MDT.

Setelah instrumen divalidasi oleh para ahli, instrumen 4T-MDT kemudian diuji coba kelas kecil sebanyak 36 siswa SMA Negeri 4 Semarang. Data tersebut diolah untuk menentukan analisis butir instrumen 4T-MDT pada validitas, reliabilitas, tingkat kesukaran, dan daya beda soal. Hasil data dianalisis oleh uji validitas product moment. 


\section{HASIL DAN PEMBAHASAN}

Pengembangan instrumen 4T-MDT menggunakan model 4D. Pada tahap Define, dilakukan analisis kebutuhan, analisis kurikulum, dan analisis materi. Hal ini berdasarkan angket dan wawancara yang sudah dilakukan ke siswa SMA Negeri 4 Semarang. Berdasarkan hasil analisis angket pendahuluan, diperoleh bahwa untuk materi fisika SMA Kelas XII yang paling banyak mengalami kesulitan yaitu materi tentang magnet. Oleh karena itu, dikembangkan 4TMDT untuk melihat seberapa besar tingkat miskonsepsi siswa terhadap materi medan magnet.

Pada tahap Design, membuat desain instrumen 4T-MDT. Instrumen 4T-MDT yang dbuat meliputi petunjuk mengerjakan soal, membuat model soal, membuat kisi-kisi pertanyaan 4T-MDT, menulis pertanyaan dalam bentuk pilihan ganda pada tingkat pertama, menuliskan pilihan jawaban, menuliskan pilihan keyakinan dari jawaban pada tingkat ke-2, menuliskan pilihan alasan dari jawaban pada tingkat ke-3, serta menuliskan pilihan keyakinan terhadap alasan pada tingkat ke-4 dan menulis kunci jawaban.

Pada tahap develop (pengembangan), Instrumen 4T-MDT yang sudah dibuat sebanyak 20 butir item divalidasi oleh enam pakar yang ahli di bidangnya. Tujuan dilakukan penilaian oleh para pakar adalah untuk mengetahui kelayakan 4T-MDT. Penilaian dilakukan oleh 6 validator yaitu pakar materi fisika, pakar bahasa, dan pakar evaluasi pendidikan. Hasil penilaian ahli terlihat pada gambar 1 .

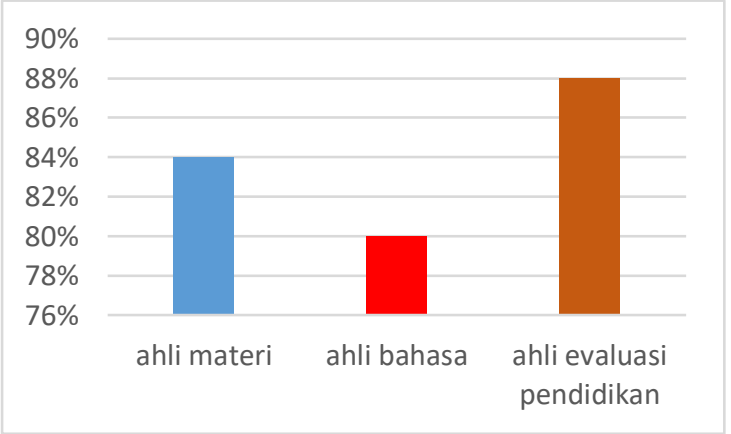

Gambar 1. Hasil penilaian kelayakan 4T-MDT pakar materi, bahasa, dan evaluasi pendidikan
Berdasarkan gambar 1 diperoleh nilai pakar materi sebesar $84 \%$, ahli bahasa sebesar $80 \%$ dan ahli evaluasi pendidikan sebesar $88 \%$. Sehingga rata-rata validasi instrumen 4T-MDT diperoleh $84 \%$ dengan kategori "Layak". Oleh karena itu instrumen 4T-MDT dapat dilanjutkan untuk uji coba kelas kecil ke siswa. Ada beberapa saran dari para ahli yaitu 1) tampilan gambar harus jelas, 2) dalam membuat pilihan ganda gunakan faktor pengecoh, 3) ada beberapa Bahasa yang masih ambigu dan segera diperbaiki, 4) jangan ada makna negatif dalam membuat pertanyaan.

Langkah selanjutnya adalah uji coba kelas kecil ini untuk melihat analisis butir soal. Uji coba kelas kecil dilakukan ke siswa SMA Negeri 4 Semarang kelas XII sejumlah 36 siswa. Siswa diminta untuk mengerjakan 20 item bentuk 4T-MDT yang dilengkapi dengan CRI (Certainty Reality Index) untuk diperoleh validitas, reliabilitas, tingkat kesukaran, dan daya beda untuk setiap item pada instrumen 4T-MDT.

Dari 20 item butir 4T-MDT terdapat 15 butir yang valid yaitu nomor 1-3, 5$8,10,12,13,15-17,19$, dan 20. Sedangkan butir item 4T-MDT yang tidak valid terdapat pada butir nomor 4, 9, 11, 14, dan 18. Pada tingkat kesukaran soal 4T-MDT terdapat item soal kategori mudah pada butir item nomor 4,10, 11, 14, dan 18. Sedangkan butir soal kategori sedang pada butir nomor 1-3, 5-8, 12, 15-17, dan 20. Butir soal kategori sukar terdapat pada butir nomor 9, 13, dan 19.

Pada kategori daya beda soal terdapat kategori sangat rendah yang terdapat pada butir soal nomor 4, 9, 11, 14, dan 18. Kategori cukup ada tiga butir nomor 12, 13, dan 19. Untuk kategori baik terdapat pada item nomor 1, 2, 5, 6, 10, dan 13-17. Sedangkan pada kategori baik sekali terdapat pada item nomor 3, 7, 8, dan 20.

Pada uji reliabilitas diperoleh hasil $r_{\text {hitung }}=0,78$, artinya soal dinyatakan reliabel dalam kategori tinggi. Berdasarkan analisis butir soal tersebut terdapat 5 soal yang memiliki nilai daya beda yang rendah, sehingga soal tersebut dieliminasi. Dengan 
demikian, dapat disimpulkan bahwa instrumen yang layak digunakan adalah 15 item pada instrumen 4T-MDT.

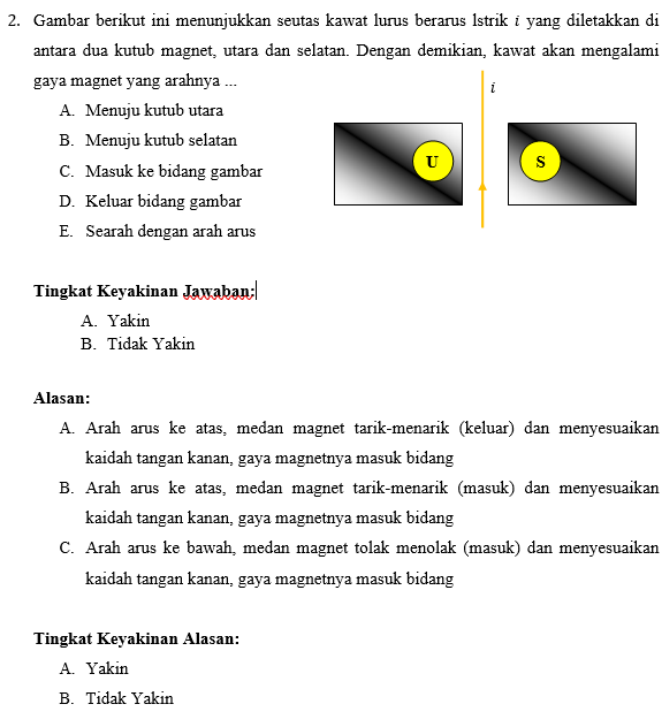

Gambar 2. Item four tier test

Gambar 2 salah satu isi butir soal pada 4T-MDT. Pada 4T-MDT, tingkatan pertama pada butir soal merupakan pernyataan soal, tingkat ke-2 pada butir soal menunjukkan keyakinan siswa terhadap pilihan jawaban siswa, tingkat ket-3 merupakan alasan atas jawaban pilihan siswa, dan tingkat ke-4 menunjukkan keyakinan siswa terhadap alasan jawaban tersebut.

Instrumen 4T-MDT terdiri dari butir soal yang masuk dalam kategori $\mathrm{C} 1$ sampai C6 sesuai dengan Taksonomi Bloom. Instrumen 4T-MDT yang dikembangkan ini mengharuskan siswa untuk dapat berpikir tingkat tinggi (HOTS) serta menggambarkan profil miskonsepsi siswa pada materi medan magnet. Siswa dalam berkemampuan berpikir tingkat tinggi (HOTS) akan dapat membedakan gagasan dengan benar, mampu berkomunikasi dengan baik, mampu memecahkan solusi dari suatu permasalahan, mampu menjelaskan konsep, mampu menjelaskan hipotesis dan memahami hal-hal yang kompleks, sehingga siswa memiliki kemampuan bernalar yang baik (Anggara, 2020; Dinni, 2018; Pamilih et al., 2019). Oleh karena itu HOTS sangat penting dimiliki oleh siswa dalam belajar fisika.

Miskonsepsi sangat berbahaya bagi siswa, sehingga harus dideteksi sedini mungkin. Dampak negatif miskonsepsi antara lain dapat mengakibatkan rendahnya konsep penguasaan materi sehingga hasil belajarnya juga rendah, miskonsepsi jika dibiarkan begitu saja akan berakibat fatal yang jika terusterusan dilakukan oleh siswa maka siswa akan menggunakan kosnep yang salah untuk diterapkan dalam permasalahan sehari-hari.

Oleh karena itu, banyak penelitian telah mengembangkan tes diagnostik untuk kesalahpahaman, seperti pengembangan tes diagnostik 2 tingkat untuk mendeteksi kesalahpahaman, pengembangan tes diagnostik berupa tes 3 tingkat untuk menentukan karakteristik miskonsepsi, dan pengembangan tes diagnostic 4 tingkat untuk mengungkap miskonsepsi siswa. Pada dasarnya siswa paham terhadap teori namun sering kali salah paham terhadap teori tersebut. Tes diagnostic jenis pilihan ganda 4 tingkat dirancang untuk mengetahui profil miskonsepsi pada siswa secara detail dengan mengkategorikan dalam empat kelompok yaitu memahami konsep, memahami konsep sebagian, tidak memahami konsep serta miskonsepsi (Ramadhan et al., 2019; Yuberti et al., 2020).

Instrumen $\quad 4 \mathrm{~T}-\mathrm{MDT} \quad$ yang

dikembangkan dalam bentuk jenis tes pilihan ganda. Tes pilihan ganda adalah alternatif terbaik untuk mendiagnosis sejumlah besar kesalahpahaman siswa. Karena lebih efektif dan efisien serta memiliki validitas dan reliabilitas yang lebih baik daripada metode wawancara (Sukarelawan et al., 2019).

Sejalan dengan penelitian Wahyuni (Wahyuni et al., 2021), instrumen four tier test yang dikembangkan pada materi gerak melingkar dapat digunakan untuk mengetahui miskonsepsi siswa. Setyaningsih juga menjelaskan pada penelitiannya mengenai analisis miskonsepsi siswa pada konsep medan magnet, membuktikan bahwa Sebagian besar siswa tidak memahami konsep gaya medan magnet sangat tinggi sehingga perlu dilakukan pengujian dengan tes diagnostik.

Tes diagnostik four tier test salah satu upaya menanggulangi miskonsepsi fisika pada 
siswa. Dari hasil tes ini, guru dapat merancang metode pembelajaran, memilih media pembelajaran yang tepat serta dapat mengidentifikasi miskonsepsi siswa pada materi medan magnet, sehingga siswa memiliki pemahaman konsep yang benar.

\section{PENUTUP}

Berdasarkan hasil analisis, dapat disimpulkan bahwa instrumen 4T-MDT yang dikembangkan mendapatkan persentase ratarata validasi sebesar $84 \%$. Hasil uji coba sebanyak 15 item soal instrumen yang memiliki validitas yang tinggi, reliabiltas yang tinggi, daya beda yang baik, dan tingkat kesukaran yang baik. Sehingga dapat digunakan untuk mengetahui profil miskonsepsi fisika siswa pada materi medan magnet. Instrumen 4T-MDT mampu memetakan konsepsi pada materi medan magnet dan 4T-MDT ini dapat digunakan sebagai alternatif instrumen dalam melakukan evaluasi pada pembelajaran fisika untuk mengurangi miskonsepsi fisika pada siswa.

\section{UCAPAN TERIMAKASIH}

Terima kasih kepada Kementerian Pendidikan Kebudayaan, Riset, Dan Teknologi dan Direktorat Jenderal Pendidikan Tinggi, Riset, Dan Teknologi yang telah memberikan pendanaan pada Penelitian Terapan Unggulan Perguruan Tinggi (PTUPT) Tahun 2021. Terimakasih juga kepada LLDIKTI Wilayah III dan LPPM Universitas Indraprasta PGRI yang telah memberikan support pada kegiatan PTUPT.

\section{REFERENSI}

Anggara, B. (2020). Pengembangan Soal Higher Order Thinking Skills Sebagai Tes Diagnostik Miskonsepsi Matematis Siswa SMA. Algoritma: Journal of Mathematics Education, 2(2), 176-191.

Astuti, B., Fitrianingrum, A. M., \& Sarwi, S. (2018). Penerapan Instrumen Three-Tier Test untuk Mengidentifikasi Miskonsepsi Siswa SMA pada Materi Keseimbangan
Benda Tagar. Phenomenon: Jurnal Pendidikan MIPA, 7(2), 88-98.

Caleon, I. S., \& Subramaniam, R. (2010). Do students know what they know and what they don't know? Using a four-tier diagnostic test to assess the nature of students' alternative conceptions. Research in Science Education, 40(3), 313-337.

Dinni, H. N. (2018). HOTS (High Order Thinking Skills) dan kaitannya dengan kemampuan literasi matematika. PRISMA, Prosiding Seminar Nasional Matematika, 1, 170-176.

Fakhrudin, Azizahwati, \& Rahmi, Y. (2012). Analisis Penyebab Miskonsepsi Siswa pada Pelajaran Fisika di Kelas XII SMA/MA Kota Duri. Jurnal Pendidikan Matematika, $\quad 3(1), \quad$ 87-98. https://doi.org/10.36709/jpm.v3i1.1988

Fariyani, Q., \& Rusilowati, A. (2015). Pengembangan Four-Tier Diagnostic Test Untuk Mengungkap Miskonsepsi Fisika Siswa Sma Kelas X. Journal of Innovative Science Education, 4(2).

Leoni, L., Maison, M., \& Muslim, M. (2020). Pengembangan Instrumen Tes Four-Tier untuk Mengidentifikasi Miskonsepsi Siswa Pada Materi Operasi Bentuk Akar. Jurnal Cendekia: Jurnal Pendidikan Matematika, 4(2), 771-778.

Pamilih, A., Sudarmi, M., \& Pattiserlihun, A. (2019). Remediasi Miskonsepsi Hukum Newton melalui HOTS (Higher Order Thinking Skills). Radiasi: Jurnal Berkala Pendidikan Fisika, 12(2), 46-53.

Ramadhan, D., Bobby, I., Ashnam, M., Alfianda, R., Marpaung, M. A., \& Sugihartono, I. (2019). Studi Miskonsepsi Medan Magnetik Menggunakan Metode Four Tier Test Untuk Siswa Sma Kelas Xii. Seminar Nasional Fisika 2019, VIII, 329-336. https://doi.org/10.21009/03.s nf2019.01.pe.42

Setyaningsih, E., Harijanto, A., \& Prastowo, S. H. B. (2018). Identifikasi Miskonsepsi Materi Medan Magnet Menggunakan Three Tier Test pada Siswa Kelas XII SMA di Jember. Seminar Nasional Pendidikan Fisika 2018, 3(2015), 167172.

Sukarelawan, M. I., Jumadi, J., \& Rahman, N. 
A. (2019). An Analysis of Graduate Students' Conceptual Understanding in Heat and Temperature (H\&T) Using Three-Tier Diagnostic Test. Indonesian Review of Physics, 2(1), 9. https://doi.org/10.12928/irip.v2i1.910.

Treagust, D. F. (2012). Diagnostic assessment in science as a means to improving teaching, learning and retention. Proceedings of The Australian Conference on Science and Mathematics Education.

Wahyuni, N., Bhakti, Y. B., Mutakin, T. Z., \& Astuti, I. A. D. (2021). The Development of Four-Tier Diagnostic Test Instrument to Identify the Learners' Misconception on Circular Motions. Impulse: Journal of Research and Innovation in Physics Education, 1(1), 24-31. https://doi.o rg/10.14421/impulse.2021.11-03.

Yuberti, Y., Suryani, Y., \& Kurniawati, I. (2020). Four-Tier Diagnostic Test with Certainty of Response Index to Identify Misconception in Physics. Indonesian Journal of Science and Mathematics Education, 3(2), 245-253. https://doi .org/10.24042/ijsme.v3i2.6061.

Zulvita, R., \& Halim, A. (2017). Identifikasi dan remediasi miskonsepsi konsep hukum newton dengan menggunakan metode eksperimen di man darussalam. Jurnal Ilmiah Mahasiswa Pendidikan Fisika, 2(1), 128-134. 